\title{
The Effect of Pumpkin Seeds Biscuits and Moringa Extract Supplementation on Hemoglobin, Ferritin, C-reactive protein, and Birth Outcome for Pregnant Women: A Systematic Review
}

\author{
Musaidah Musaidah $^{1 *}$, Atjo Wahyu ${ }^{2}$, Andi Zulkifli Abdullah², Muhammad Syafar², Veni Hadju ${ }^{3}$, Aminuddin Syam $^{3}$ \\ ${ }^{1}$ Doctoral Student in Public Health, Faculty of Public Health, Hasanuddin University, Makassar, Indonesia; ${ }^{2}$ Department of \\ Public Health, Faculty of Public Health, Hasanuddin University, Makassar, Indonesia; ${ }^{3}$ Department of Nutrition, Faculty of \\ Public Health, Hasanuddin University, Makassar, Indonesia
}

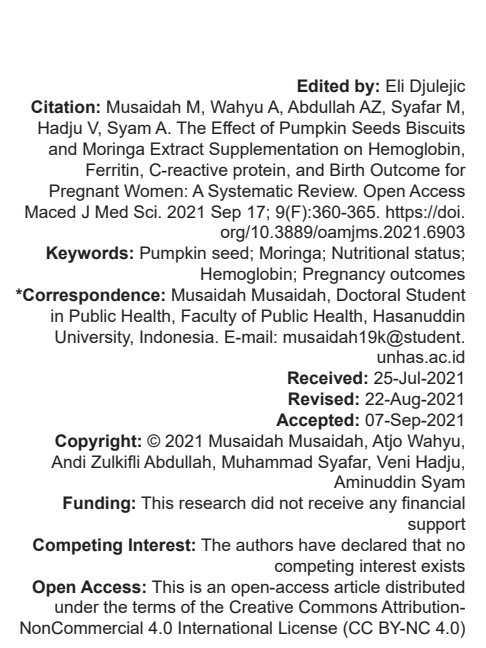

\begin{abstract}
BACKGROUND: According to the WHO data, $40 \%$ of maternal mortality in developing countries is related to anemia in pregnancy. Most anemia in pregnancy is caused by iron deficiency and acute bleeding, sometimes even the two interact. The incidence of anemia in pregnancy in Indonesia is quite high, which is around $67 \%$ of all pregnant women, with variations depending on each region. About $10-15 \%$ of pregnant women are classified as severe anemia which of course will affect the growth and development of the fetus in the womb. Most of the anemia in pregnant women occurs due to malnutrition.
\end{abstract}

AIM: The objective of the study was to review journals related to the effect of pumpkin seed biscuits and Moringa capsules on hemoglobin $(\mathrm{Hb})$, ferritin, and C-reactive protein (CRP) levels in pregnant women and also the prevention of stunting.

METHODS: Study of literature by collecting relevant literature using online journal data based on PUBMED, Google Search, ELSEVIER, MDPI, DOAJ (Direct Directory of Open Access Journals), or from the bibliography of the articles being searched.

RESULTS: Supplementary food was given to pregnant women by giving pumpkin seeds and Moringa leaf extract impact on improving nutritional status, $\mathrm{Hb}$, ferritin, and CRP levels in pregnant women, as well as preventing adverse pregnancy outcomes such as low birth weight.

CONCLUSION: The provision of pumpkin seed biscuits and Moringa leaf extract to pregnant women can affect $\mathrm{Hb}$ ferritin, and CRP levels and can affect maternal nutritional status and affect pregnancy outcomes.

\section{Introduction}

Pregnancy is the growth and development of an intrauterine fetus from conception and ending until the onset of labor. The duration of gestation is estimated at 280 days (40 weeks) and not more than 300 days (43 weeks). According to the $\mathrm{WHO}$ data, $40 \%$ of maternal deaths in developing countries are related to anemia during pregnancy. Most anemia in pregnancy is caused by iron deficiency and acute bleeding, sometimes even the two interact. The incidence of anemia in pregnancy in Indonesia is quite high, which is around $67 \%$ of all pregnant women, with variations depending on each region. Iron metabolism is influenced by various factors, one of which is protein [1]. Protein has an important role in providing organic iron intake. Organic iron is obtained from food intake, especially in red meat [2], and is an important functional unit for binding iron and preventing potential toxic oxidants in the form of hemoproteins as heme compounds (hemoglobin [Hb] or myoglobin) and heme enzymes. Ferritin is an iron storage protein and is present extracellularly in serum. Ferritin serves as a clinical marker of the status of the body's iron stores [3]. Iron deficiency anemia caused significant increase in platelet count (PT) and total iron-binding capacity (TIBC) [4].

The WHO data report that babies with low birth weight (LBW) account for $60-80 \%$ of all neonatal deaths and have a risk of death 20 times greater than babies with normal weight. The percentage of LBW in developing countries is $16.5 \%$, twice as large as in developed countries (7\%) [5]. Long-term impact of LBW is stunting. Stunting is a physical growth disorder characterized by a decrease in growth rate and is a result of nutritional imbalances. Stunting is still a nutritional problem in Indonesia that has not been resolved. Stunting will cause long-term impacts, namely, disruption of physical, mental, intellectual, and cognitive development. Children who are stunted until the age of 5 years will be difficult to repair so that it will continue into adulthood and can increase the risk of offspring with LBW [6].

Pregnant women should meet the requirement for certain nutrients, especially micronutrients to ensure 
the better pregnancy outcome later on. Efforts to fulfill the nutritional status of pregnant women and babies can be fulfilled with a good source of nutrition, namely, pumpkin fruit and Moringa leaf. The pumpkin plant is a type of fruit that belongs to the Cucurbitaceae family, including seasonal plants that bear fruit immediately after death. Pumpkin seeds are a plant that is easy in the nursery, care, and the results are sufficient to provide high economic value to the community. Pumpkin seeds are widely cultivated in African countries, America, India, and China. Pumpkin seeds usually grow in low and high plains, altitudes between $0 \mathrm{~m}$ and $1500 \mathrm{~m}$ above sea level [7].

Pumpkin seeds are a plant that is easily found in Indonesia. However, the use of pumpkin seeds in the community is still minimal. Cucurbita moschata seeds contain several substances, including a type of amino acid such as m-carboxyphenylalanine, amino butyrate, and citrulline as well as a number of other amino acids needed by the prostate gland such as seminal alanine, glycine, and glutamic acid. These seeds also contain mineral elements $\mathrm{Zn}$ (zinc) and $\mathrm{Mg}$ (magnesium) which are very important for reproductive health. Pumpkin seeds are a good source of phytoestrogens and may exert week estrogenic or anti-estrogenic effects which decrease blood pressure and reduce C-reactive protein (CRP) [8]. CRP is expressed in human atherosclerotic plaques and both vascular cells and monocytes/macrophages appear to represent a significant source of CRP in the inflammatory vessel wall [9]. Moringa oleifera leaves have long been used to overcome the problem of malnutrition among children, pregnant women, and breastfeeding. In addition, with micronutrients substances, $M$. oleifera can be used an alternative supplement for pregnant women to prevent maternal anemia and LBW.

The aim of this literature review is to assess journal article related to impact supplementation of pumpkin seeds and Moringa extract on $\mathrm{Hb}$, ferritin, CRP, and birth outcome for pregnant woman.

\section{Methods}

Study selection: The systematic review uses database from the PubMed, Scinapse, and ProQuest. The search criteria in the database use the word "pumpkin seeds," "Moringa leaf," "outcome pregnant," growth with restrictions on articles published during the past 10 years (2010-2020), English language articles, open access. The inclusion criteria were as follows: (1) Full-text articles were selected, (2) targeting studies of mother- children (under 5 years old), and (3) randomized controlled trial study. Exclusion criteria were as follows: (1) Review/editorial, (2) conference proceedings, (3) systematic review/literature review, (4) study protocol, and (5) meta-analysis. Figure 1 shows a flowchart for study based on PRISMA 2015 guidelines.

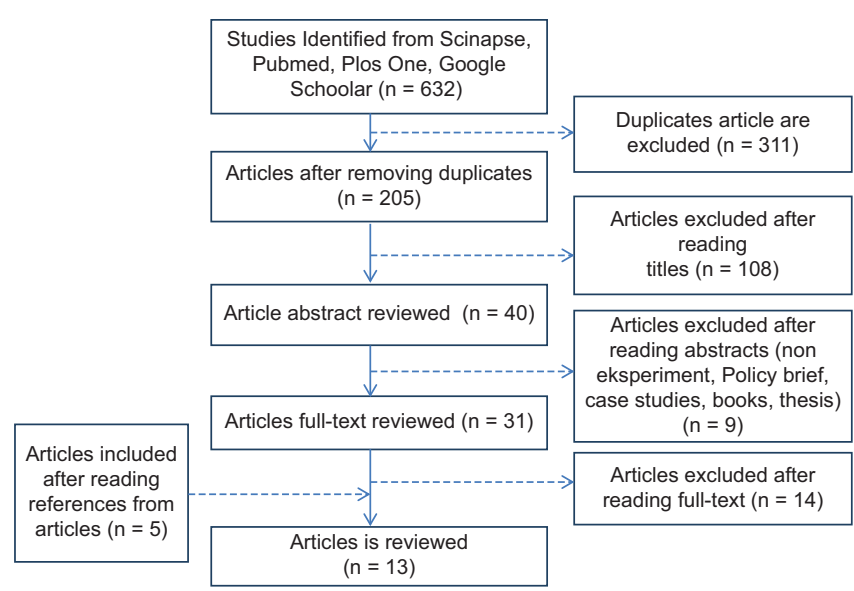

Figure 1: Flowchart for study based on PRISMA 2015 guideline

\section{Results and Discussion}

Table 1 shows that there are 13 articles that were successfully selected related to the Effect of intervention pumpkin seeds and Moringa leaf on pregnancy outcomes published in 2008 - 2019.

\section{Pumpkin seeds and Moringa leaf extract}

The chemical composition and several bioactive components such as tocopherols, carotenoids, and $ß$-sitosterol were analyzed in three main pumpkin species (Cucurbitaceae pepo, C. moschata, and Cucurbita maxima) in three parts (peeled, meat, and seeds) each of the pumpkin species. C. maxima contains more carbohydrates, protein, fat, and fiber than Cucurbita pepo or C. moschata $(p<0.05)$. The water content and amino acids and arginine content in all parts of the pumpkin are the highest in C. pepo. The main fatty acids in the seeds are palmitic, stearic, oleic, and linoleic acids. The seeds of $C$. pepo and C. moschata contain much more $\gamma$-tocopherol than $C$. maxima, whose seeds contain highest ß-carotene. C. pepo seeds contain much more ß-sitosterol than other seeds. Nutrient composition varies different between species and parts of the pumpkin [10]. Nutritional value of pumpkin seeds per $100 \mathrm{~g}$ included carbohydrates $10.71 \mathrm{~g}$, energy $559 \mathrm{kkal}$, total fat $49.05 \mathrm{gr}$, protein $30.23 \mathrm{~g}$, fiber $6 \mathrm{~g}$, cholesterol $0 \mathrm{mg}$, folic acid $58 \mu \mathrm{g}$, niacin $4.8 \mathrm{mg}$, Vitamin B5 $0.75 \mathrm{mg}$, B6 $0.14 \mathrm{mg}$, B2 $0.15 \mathrm{mg}$, thiamin $0.272 \mathrm{mg}$, Vitamin C $0.272 \mathrm{mg}$, Vitamin A $16 \mathrm{IU}$, Vitamin E $35.1 \mathrm{mg}$, mineral sodium $7.0 \mathrm{mg}$, potassium $809.0 \mathrm{mg}$, minerals cobalt $1.43 \mathrm{mg}$, iron $8.8 \mathrm{mg}$, magnesium $592 \mathrm{mg}$, mangan $4.54 \mathrm{mg}$, phosphor $1232 \mathrm{mg}$, selenium $9.40 \mu \mathrm{g}$, and zinc $7.8 \mathrm{mg}$. Phytochemical dense including betacarotenoid $9 \mu \mathrm{g}$, beta-cryptoxanthin $1 \mu \mathrm{g}$, and lutein zeaxanthin $74 \mu \mathrm{g}$ [11]. 
Table 1: Effect of intervention pumpkin seeds and Moringa leaf on outcome pregnancy

\begin{tabular}{|c|c|c|c|}
\hline S. No. & Author/place/year & Title & Study objective \\
\hline 1 & Maiya M/USA/2017 [8] & $\begin{array}{l}\text { Dissertation: Effect of } \\
\text { supplementation with pumpkin } \\
\text { seed oil versus pumpkin seeds on } \\
\text { blood pressure and menopausal } \\
\text { symptoms in non-hypertensive } \\
\text { postmenopausal women }\end{array}$ & $\begin{array}{l}\text { To compare influences pumpkin } \\
\text { seeds ( } 11 / 2 \text { teaspoons } / 4.1 \mathrm{~g} \\
\text { daily) versus pumpkin seed oil } \\
\text { ( } 2 \mathrm{~g} / \text { day) for } 12 \text { weeks on blood } \\
\text { pressure (systolic and diastolic), } \\
\text { endothelial function, plasma lipids, } \\
\text { C-reactive protein concentration, } \\
\text { and menopausal symptoms in } \\
\text { non-hypertensive postmenopausal } \\
\text { women }\end{array}$ \\
\hline 2 & $\begin{array}{l}\text { Naghii and Mofid } \\
\text { M/Iran/2008 [27] }\end{array}$ & $\begin{array}{l}\text { Impact of daily consumption of iron } \\
\text { fortified ready-to-eat cereal and } \\
\text { pumpkin seed kernels (Cucurbita } \\
\text { pepo) on serum iron in adult } \\
\text { women }\end{array}$ & $\begin{array}{l}\text { This is to determine the } \\
\text { effectiveness of consuming ready- } \\
\text { to-eat cereals and pumpkin seed } \\
\text { kernels on status of iron nutrition } \\
\text { and response of hematological } \\
\text { characteristics of women at } \\
\text { reproductive ages }\end{array}$ \\
\hline
\end{tabular}

Design

Study outcome

Pumpkin seeds help with weight loss and reduction in body fat percent which is most likely due to the benefits of satiety from high protein and fiber content in pumpkin seeds. Pumpkin seed oil supplementation confirmed previous findings suggest a significant reduction in diastolic blood pressure and menopause symptoms, small improvements in low-density lipoprotein and total cholesterol, and decreased C-reactive protein

Experiment study Better response for iron status was observed after intervention. The statistical analysis showed a significant difference between the pre and post consumption phase for higher serum iron $(60 \pm 22 \mathrm{vs}$. $85 \pm 23 \mathrm{ug} / \mathrm{dl})$, higher transferrin saturation percent ( $16.8 \pm 8.0$ vs. $25.6 \pm 9.0 \%)$, and lower total iron binding capacity $(367 \pm 31$ vs. $339 \pm 31 \mathrm{ug} / \mathrm{dl})$. A significant positive correlation $(r=0.981, p=0.000)$ between the differences in serum iron levels and differences in transferrin saturation percentages and a significant negative correlation $(r=-0.916, p<0.001)$ between the differences in serum iron levels and differences in total iron binding capacity There was significant increment in the

3 Resmi et al. /India/2017 [16] Effectiveness of amla, jaggery and Assessing the effectiveness of pumpkin leaves extract on the level a mixture of amla, jaggery, and of hemoglobin, Vitamin C, and iron pumpkin leaves on hemoglobin, among adolescent girls with iron Vitamin $\mathrm{C}$, and iron levels in deficiency anemia

adolescent girls with iron deficiency anemia

4 Soltan SSA/Egypt/2013 [4] The protective effect of soybean, sesame, lentils, pumpkin seeds, and molasses on iron deficiency anemia in rats

To determine the protective effect of cooked soybeans, ripe lentils, sesame seeds, pumpkin seeds, molasses, and their mixtures (soy + lentils + sesame seeds + pumpkin seed powder + molasses) with ascorbic acid against iron deficiency anemia

Randomized to the There was significant increment in the
pre-test and post-test level of hemoglobin $\begin{array}{ll}\begin{array}{l}\text { control and experimental } \\ \text { group }\end{array} & \text { Vitamin C, and iron of the subjects in the }\end{array}$ experimental group. In the experimental group, there was a rise in mean values for hemoglobin from 9.942 to 10.99 , Vitamin $\mathrm{C}$ from 4.302 to 5.63 , and iron from 77.6 to 99.58

Randomized to the Rats fed on iron-free diet supplemented control and experimental with seven iron sources revealed significant group increase in hemoglobin, Hct, mean corpuscular volume, mean corpuscular hemoglobin,, mean corpuscular hemoglobin concentration, red blood cell, white blood cell, serum iron, and significant decreased in platelet count and total iron-binding capacity. Mixture of legumes, cereals, and molasses with ascorbic acid and molasses with ascorbic acid has protection against iron deficiency anemia and is equivalent to FesO

to FeSO

To determine the effect of pumpkin seed supplementation (Cucurbita pepo L.) on atherosclerosis due to an atherogenic diet

Randomized to the control and experimental pumpkin seeds showed a significant group decrease $(p<0.001)$ in their serum concentrations of total cholesterol and low-density lipoprotein cholesterol as they dropped from $4.89 \mathrm{mmol} / \mathrm{L}$ to $2.55 \mathrm{mmol} / \mathrm{L}$ and from $3.33 \mathrm{mmol} / \mathrm{L}$ to $0.70 \mathrm{mmol} / \mathrm{L}$, respectively. Serum concentrations of highdensity lipoprotein cholesterol were also significantly elevated in the same group Although, atherogenic rats supplemented with $2 \%$ arginine showed significant increase in serum concentration of highdensity lipoprotein-cholesterol, no significant changes were observed in their serum concentrations of total cholesterol and lowdensity lipoprotein-cholesterol

Pumpkin seed oil from C. maxima significantly reduced the degree of overactive bladder symptom score in the subjects. Pumpkin seed oil extracts from C. maxima as well as from C. pepo are effective for urinary disorders such as overactive bladder in humans
Biscuits fortified with nutritious pumpkin seed flour were made with four different levels of pumpkin seed flour substitution in wheat flour $(\mathrm{T} 2=5 \%, \mathrm{~T} 3=10 \%, \mathrm{~T} 4=15 \%$ and $\mathrm{T} 5=20 \%$ ), compared to control (T1). The chemical attributes of biscuits show that T5 has the highest levels in pumpkin flour $(20 \%)$ with the maximum protein $(12.30 \%)$, fat $(28.29 \%)$, ash $(4.13 \%)$, iron $(2.28 \%)$, and zinc $(3.11 \%)$. The sensory results also show an increasing trend in all sensory parameters

(Contd...) 
Table 1: (Continued)

\begin{tabular}{lllll}
\hline S. No. & Author/place/year & Title & Study objective & Design \\
\hline 8 & Iskandar et al., & Effect of Moringa oleifera leaf & Assess the effect of Moringa oleifera & Double-blind, \\
& /Indonesia/2015 [20] & extracts supplementation in & leaf extracts supplementation in & randomized control trial \\
& preventing maternal anemia and & preventing maternal anemia and low & study, pretest-posttest \\
& low birth weight & birth weight & controlled
\end{tabular}

Study outcome

Significant increase of hemoglobin level in

the intervention group $(p<0.05)$. Moringa

oleifera extract consumption increased the

hemoglobin level to $58 \%$. In the control

group, the conformity of pregnant women

has no significant effect to pregnant women hemoglobin level increase. Moringa oleifera extract is able to retain ferritin serum level dismount up to $50 \%$. Low birth weight was

not found in pregnant women who received Moringa oleifera leaf extract

9 Sindhu et al./Bangalore/2013 Efficacy of Moringa oleifera in [25] treating iron deficiency anemia in The objective of studying the effect Interventional study The women in intervention group showed an increase in hemoglobin level. By the in vegetable source in the form of Student's t-test, the post-intervention data Moringa oleifera and jaggery in improvement of women suffering from iron deficiency anemia are highly significant, $t=4.109(p<0.001)$ This study shows that Moringa oleifera with jaggery has significantly improved hemoglobin levels of anemic women Hemoglobin levels of a group of Moring

$10 \quad$ Nadimin et all Indonesia/2015 [26]

The extract of Moringa leaf has an equivalent effect to iron folic acid in increasing hemoglobin levels of pregnant women: a randomized control study in the coastal area of Makassar
To determine the effect of Moringa Randomized doubleleaf extract for anemia prevention in blind design, pretestpregnant women posttest controlled

leaf extract before intervention (11 $283 \pm$ $0777 \mathrm{~g} / \mathrm{dL}$ ) increased to $11754 \pm 1089 \mathrm{~g} / \mathrm{dL}$ $(p=0.040)$. Hemoglobin levels in folic iron group also increased between before and after intervention $(p=0.002)$. The amount of increase in hemoglobin concentration in folic iron group of $0.9886 \pm 1.7638 \mathrm{~g} / \mathrm{dL}$ ) highe than Moringa leaf extract group ( 0.4771 $\pm 1.3051 \mathrm{~g} / \mathrm{dL}$ ), but a large increase in hemoglobin levels between the two groups was not significant $(p=0168)$

Investigated the efficacy of Moringa A randomized, double- The result showed that there was oleifera L. leaves to extract as an blind, placebo-controlled with iron deficiency anemia

ignificantly increase hemoglobin, ferritin, mean corpuscula hemoglobin concentration, red cell distribution width, and decreased of platelets. The control groups were significantly increased of mean of the hemoglobin, erythrocytes, hematocrit, mean corpuscular volume, mean corpuscular hemoglobin, and red cell distribution width. The hematocrit, mean corpuscular hemoglobin, and mean corpuscular hemoglobin concentration values of Moringa leaves were significantly higher whereas the platelets count of Moringa leaves was significantly lower $(p<0.05)$ than those of control group

12 Sartika et al./Indonesia/2019 The effect of Moringa leaf capsule [22] on the hemoglobin levels in young women at SMP Sabbihisma Padang

13 Sihotang et al. Indonesia/2018 [23]
To determine the effect of leaf Moringa capsules on the hemoglobin levels in adolescent girls in Sabbihisma Junior High Schoo Analyze the effect of Moring (Moringa oleifera) biscuit administration on hemoglobin levels of pregnant women.
Effect of oleifera) biscuit administration on hemoglobin levels of pregnant women
Quasi method of pre-test There was a significant difference in female and post-test experiment hemoglobin levels in the case group with with control group design $p=0.000$, while the control group was not significant with $p=0.091$

Single-blind randomized Significant difference in hemoglobin levels controlled tria between the treatment group and the control group after the intervention $(p \leq 0.05)$. After the intervention, some respondents in the treatment group were not suffering from anemia. Administration of five pieces $(60 \mathrm{~g})$ of Moringa biscuit per day in pregnant women with anemia is recommended as one of the alternatives to overcome the undernutrition problem in pregnant women, especially to increase hemoglobin levels
Pumpkin seeds are rich in oil and protein and, given its fatty acid profile, it lies in the linoleic-oleic group such as cotton seed, corn, sesame, sunflower, and soybean oil. With high oil yield and physicochemicals characteristics similar to others commercial vegetable oil, pumpkin seed oil can be considered new and valuable source of vegetable oil [12]. Pumpkin seeds indicate highly nutritious and provide many nutrients essential for health [11]. Pumpkin seed extract contains both lignans and flavones. The results of Richter D et al (2013) research on experimental animals showed that a potential role of pumpkin seeds lignans in breast cancer prevention and/or treatment [13].

Moringa is reported to have excellent nutritional properties, low seed toxicity, high quality of oil, ability to purify water, and adapt to poor soils and dry climates. Variation in the nutritive values depends on genetic background, environment, and cultivation methods. Leaves had high protein $(28.4 \mathrm{~g})$ and crude fiber $(19.2 \mathrm{~g})$ content but less fat $(1.9 \mathrm{~g})$ content whereas the fat content $(0.1 \mathrm{~g})$ was almost negligible in seeds. All 10 essential amino acids were present in both leaves and seeds with similar leucine, phenylalanine, threonine, and valine content. Leaves had high isoleucine and low tryptophan content. Seeds had high arginine and low valine content. Glutamate was high followed by aspartate, glycine, serine, and alanine in leaves and seeds. Roots, leaves, and seeds of Moringa have appreciable amino acid content. Leaves had high 
calcium, potassium, sulfur, magnesium, phosphorous, and iron content whereas copper content was high in seeds. Vitamin $E$ (tocopherol) content was high in leaves whereas seeds had high Vitamin C (ascorbic acid) content. Vitamin B2 (riboflavin) content of seeds was negligible and Vitamin E was absent. Vitamin B5 (pantothenic acid) and B9 (folate) content were similar in leaves and seeds. Folate was found in both leaves and seeds. The low content of Vitamin $C$ in leaves may be due to oxidation loss during air drying at room temperature. It is thus evident that Moringa leaves are nutrient dense providing essential micronutrients. Saponins, flavonoids, steroids, glycosides, and polyphenols were present in leaves and seeds. Terpenoids were present in leaves but not in seeds. Moringa is known for its high antioxidant activity among all fruits and vegetables [14].

\section{Effect of pumpkin seeds and Moringa leaf extract on $\mathrm{Hb}$, ferritin, CRP, and outcome pregnancy}

The nutritional status of pregnant women supports the birth of a healthy baby and reduces the risk of morbidity in the baby. The fulfillment of adequate nutrition during pregnancy plays a very important role in the process of fetal growth and development. The nutritional adequacy of pregnant women will affect the condition of the fetus in its growth and development during pregnancy to the outcome of birth.

\section{Predlog promena}

Pregnant women have nutrition intervention through iron supplementation, folic acid, MMN, Vitamin $D$, and zinc supplementation which has an impact on pregnancy outcomes. Intervention of pregnant women through pumpkin seed biscuits is expected to have an impact on $\mathrm{Hb}$, ferritin, CRP levels, LBW, and reduces the incidence of stunting in children. Pumpkin seeds are a good source of phytoestrogens and may exert week estrogenic or anti-estrogenic effects. Studies in postmenopausal women have demonstrated that pumpkin seed oil, at a dose of $2 \mathrm{~g}$ per day for 12 weeks, can decrease blood pressure and reduce menopausal symptoms also decrease CRP [8]. Intervention with ready-to-eat cereal (providing $7.1 \mathrm{mg}$ iron/day) plus $30 \mathrm{~g}$ of pumpkin seed kernels (providing $4.0 \mathrm{mg}$ iron/day) for 4 weeks contributes to maintaining optimal nutritional status and minimizing the likelihood of iron insufficiencies in woman reproductive age which was increasing of serum iron, percent transferrin saturation, and reducing TIBC [15]. The formulation of amla, jaggery, and pumpkin leaves shows a greater potential in the combination therapy of herbal medicines in the management of anemia which was influence to increase hemoglobin, Vitamin C, and iron plasma in adolescents girls with iron deficiency anemia [16]. Study in Egypt was showed that supplementation of cooked soybean, cooked lentils, sesame seed, pumpkin seed, molasses, and mixture of them (soybean + lentils + sesame seed + Pumpkin seed powder + molasses) with ascorbic acid in rats revealed significant increase in $\mathrm{Hb}$, Hct, mean corpuscular volume, mean corpuscular $\mathrm{Hb}, \mathrm{MCH}$ concentration $(\mathrm{MCHC})$, red blood cell, white blood cell, serum iron, and significant decreased in PT and TIBC [4]. Treatment of atherogenic rats with pumpkin seeds significantly decreased serum concentrations of total cholesterol and low-density lipoprotein-cholesterol, which explained pumpkin seeds supplementation has a protective effect against atherogenic [17]. Pumpkin seed oil extracted from C. maxima has the potential for prevention or treatment of urinary disorders including dysfunction urinary tract on human overactive bladder [18]. Study supplementation pumpkin seeds biscuit to combat malnutrition in Pakistan was showed that pumpkin seed flour can be supplemented successfully to partially replace wheat flour to prepare highly nutritious biscuits without affecting its overall acceptability [19].

Intervention of pregnant women through Moringa leaf extract capsules is expected to have an impact on $\mathrm{Hb}$, ferritin, CRP levels, LBW, and reduces the incidence of stunting in children. Supplementation of M. oleifera leaf extracts significant increases of $\mathrm{Hb}$ level to $58 \%$ compared with the control group, M. oleifera extract is able to retain ferritin serum level dismount up to $50 \%$ [20]. Intervention of $M$. oleifera L. leaves significantly increased of mean $\mathrm{Hb}$, ferritin, $\mathrm{MCHC}$, and red cell distribution width and decreased of platelets. One thousand and four hundred milligrams of Moringa extract per day increased significantly hemoglobin and the result higher than control group [21]. Moringa leaf capsule can increase $\mathrm{Hb}$ level of adolescent girl, especially for anemia [22]. Supplementation of $M$. oleifera biscuit significant influences the increasing of hemoglobin in pregnancy anemia [23].

Moringa extract give evidence to utilize local food in order to prevent anemia and adverse pregnancy outcome [24]. M. oleifera has significantly increased hemoglobin concentration among anemic women [25]. Intervention of Moringa leaf significant increasing $\mathrm{Hb}$ levels of pregnant women [26]. For birth weight, supplementation using Moringa extract has positive effect on LBW prevention [20].

\section{Conclusion}

The provision of pumpkin seed biscuits and Moringa leaf extract to pregnant women can affect $\mathrm{Hb}$, ferritin, and CRP levels and can affect maternal nutritional status and affect pregnancy outcomes. 


\section{References}

1. Di Renzo GC, Spano F, Giardina I, Brillo E, Clerici G, Roura LC. Iron deficiency anemia in pregnancy. Womens Health. 2015;11(6):891-900. https://doi.org/10.2217/whe.15.35 PMid:26404445

2. Hooda J, Shah A, Zhang L. Heme, an essential nutrient from dietary proteins, critically impacts diverse physiological and pathological processes. Nutrients. 2014;6(3):1080-102. https:// doi.org/10.3390/nu6031080

PMid:24633395

3. Knovich MA, Storey JA, Coffman LG, Torti SV, Torti FM. Ferritin for the clinician. Blood Rev. 2009;23(3):95-104. https://doi. org/10.1016/j.blre.2008.08.001

PMid:18835072

4. Soltan SS. The protective effect of soybean, sesame, lentils, pumpkin seeds and molasses on iron deficiency anemia in rats. World Appl Sci J. 2013;23:795-807.

5. Putri AW, Pratitis A, Luthfiya L, Wahyuni S, Tarmali A. Faktor ibu terhadap kejadian bayi Berat Lahir Rendah. HIGEIA J Public Health Res Dev. 2019;3(1):55-62. https://doi.org/10.21109/ kesmas.v1i3.304

6. Losong NH, Adriani M. Perbedaan Kadar hemoglobin, Asupan Zat Besi, dan Zinc pada Balita Stunting dan Non Stunting. Am Nutr. 2017;1(2):117-23. https://doi.org/10.20473/amnt. v1i2.2017.117-123

7. Heliyani HD. Pengembangan produk pangan berbahan baku labu kuning. J Peningkatan Daya Saing Pangan Tradisional. 2012;2(1):134-40.

8. Maiya M. Effect of supplementation with pumpkin seed oil versus pumpkin seeds on blood pressure and menopausal symptoms in non-hypertensive postmenopausal women. In: Dissertation: Department of Nutrition and Food Sciences College of Health Sciences, Denton, Texas; 2017.

9. Nery MR, Imelda C. The effects of malunggay (Moringa oleifera) leaves capsule supplements on high specificity C-reactive protein and hemoglobin A1c levels of diabetic patients in Ospital ng maynila medical center: A prospective cohort study. Philippine J Intern Med. 2015;53(4):1-10.

10. Kim MY, Kim EJ, Kim YN, Choi C, Lee BH. Comparison of the chemical compositions and nutritive values of various pumpkin (Cucurbitaceae) species and parts. Nutr Res Pract. 2012;6(1):21-7. https://doi.org/10.4162/nrp.2011.5.6.21 PMid:22413037

11. Syed $Q A$, Akram M, Shukat R. Nutritional and therapeutic importance of the pumpkin seeds. Seed. 2019;21(2):15798-803.

12. Gohari AA, Farhoosh R, Haddad KM. Chemical composition and physicochemical properties of pumpkin seeds (Cucurbita pepo Subsp. pepo Var. Styriaka) grown in Iran. J Agric Sci Technol. 2011;13:135.

13. Richter D, Abarzua S, Chrobak M, Vrekoussis T, Weissenbacher T, Kuhn C, et al. Effects of phytoestrogen extracts isolated from pumpkin seeds on estradiol production and ER/PR expression in breast cancer and trophoblast tumor cells. Nutr Cancer. 2013;65(5):739-45. https://doi.org/10.1080/0 1635581.2013.797000

PMid:23859042
14. Chelliah R, Ramakrishnan S, Antony U. Nutritional quality of Moringa oleifera for its bioactivity and antibacterial properties. Int Food Res J. 2017;24(2):825.

15. Naghii MR, Mofid M. Impact of daily consumption of iron fortified ready-to-eat cereal and pumpkin seed kernels (Cucurbita pepo) on serum iron in adult women. Biofactors. 2007;30(1):19-26. https://doi.org/10.1002/biof.5520300103

PMid:18198398

16. Resmi S, Latheef F, Vijayaraghavan. Effectiveness of amla, jaggery and pumpkin leaves extract on the level of haemoglobin, Vitamin $C$ and iron among adolescent girls with iron deficiency anemia. Int J Pharm Sci Res. 2017;8(11):4812-7. https://doi. org/10.7897/2277-4343.084219

17. Abuelgassim AO, Al-Showayman SI. The effect of pumpkin (Cucurbita Pepo L) seeds and L-arginine supplementation on serum lipid concentrations in atherogenic rats. Afr $\mathrm{J}$ Tradit Complement Altern Med. 2012;9(1):131-7. https://doi. org/10.4314/ajtcam.v9i1.18

PMid:23983330

18. Nishimura M, Ohkawara T, Sato H, Takeda H, Nishihira J. Pumpkin seed oil extracted from Cucurbita maxima improves urinary disorder in human overactive bladder. J Tradit Complement Med. 2014;4(1):72-4. https://doi.org/10.4103/2225-4110.124355 PMid:24872936

19. Kanwal S, Raza S, Naseem K, Amjad M, Bibi N, Gillani M. Development, physico-chemical and sensory properties of biscuits supplemented with pumpkin seeds to combat childhood malnutrition in Pakistan. Pak J Agric Res. 2015;28(4):400-5.

20. Iskandar I, Hadju V, As'ad S, Natsir R. Effect of Moringa oleifera leaf extracts supplementation in preventing maternal anemia and low-birth-weight. Int J Sci Res Public 2015;5(2):1-3.

21. Suzana D, Suyatna FD, Andrajati R, Santi PS, Mun'im A. Effect of Moringa oleifera leaves extract against hematology and blood biochemical value of patients with iron deficiency anemia. J Young Pharm. 2017;9(1):S79. https://doi.org/10.5530/ jyp.2017.1s.20

22. Sartika W, Suryarinilsih Y. The Effect of Moringa Leaf Capsule On the Hemoglobin Levels in Young Women at Smp Sabbihisma Padang. United States: KnE Life Sciences; 2019. p. 158-64. https://doi.org/10.18502/kls.v4i15.5753

23. Sihotang PC, Candriasih P, Amdadi S. Effect of Moringa (Moringa oleifera) Biscuit administration on hemoglobin levels of pregnant women. Int J Sci Basic Appl Res. 2018;37(1):243-52.

24. Nurdin MS, Imam A, Thahir A, Hadju V. Supplementations on pregnant women and the potential of Moringa oleifera supplement to prevent adverse pregnancy outcome. Int J Sci Healthc Res. 2018;3(1):71-5.

25. Sindhu S, Mangala S, Sherry B. Efficacy of Moringa oleifera in treating iron deficiency anemia in women of reproductive age group. Int J Physiother Res. 2013;3(4):15-20.

26. Nadimin HV, As'ad S, BuchariA. The extract of Moringa leaf has an equivalent effect to iron folic acid in increasing hemoglobin levels of pregnant women: A randomized control study in the coastal area of Makassar. Int J Sci Basic Appl Res. 2015;22(1):287-94. https://doi.org/10.5958/0976-5506.2019.00102.5

27. Naghii MR, Mofid M. Impact of daily consumption of iron fortified ready-to-eat cereal and pumpkin seed kernels (Cucurbita pepo) on serum iron in adult women. Biofactors. 2007;30(1):19-26. PMid: 18198398 